SNOW CRYSTALS 


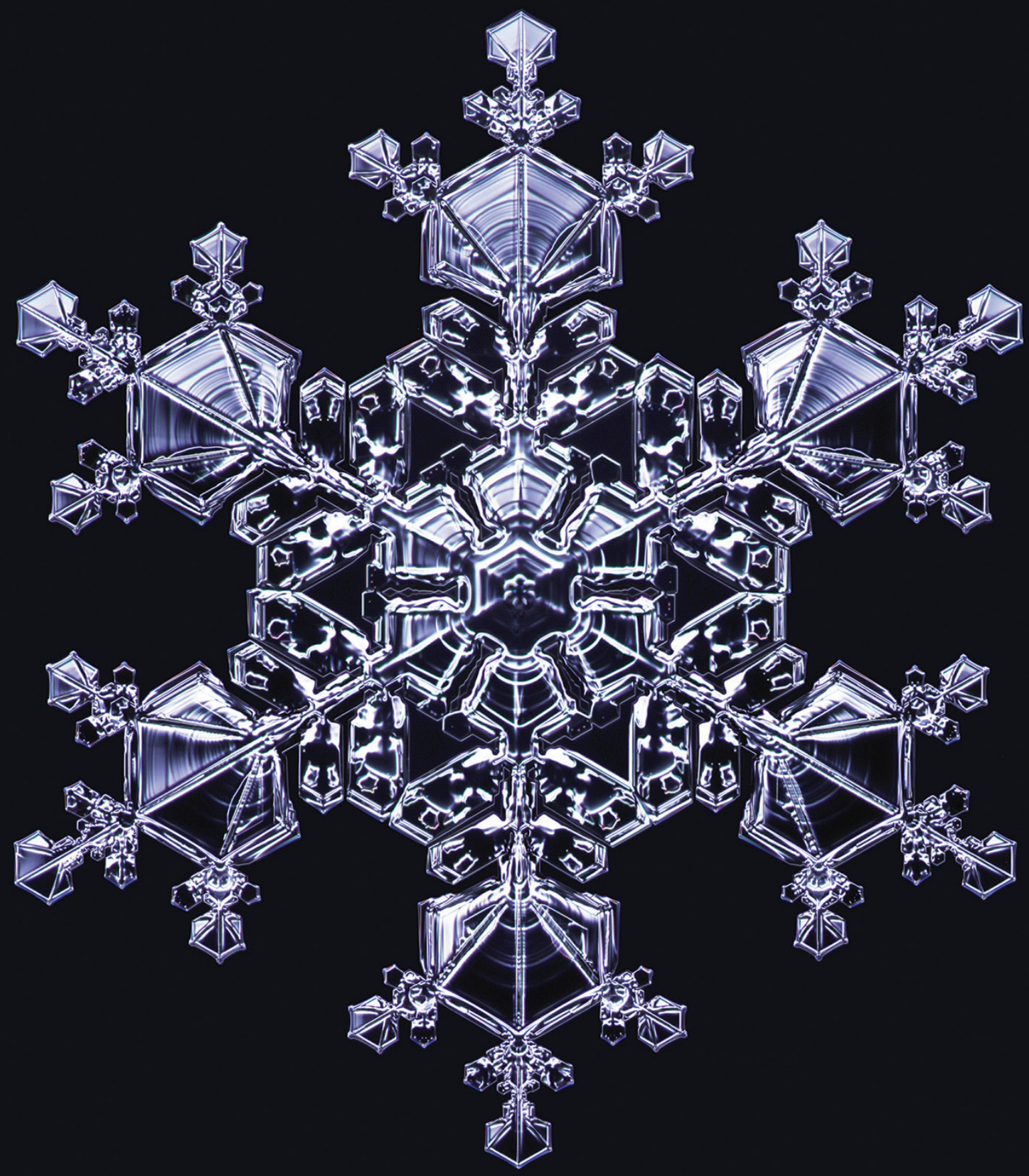




\section{Snow Crystals}

\section{A Case Study in Spontaneous \\ Structure Formation}

\section{Kenneth G. Libbrecht}


Copyright (c) 2022 by Princeton University Press

Princeton University Press is committed to the protection of copyright and the intellectual property our authors entrust to us. Copyright promotes the progress and integrity of knowledge. Thank you for supporting free speech and the global exchange of ideas by purchasing an authorized edition of this book. If you wish to reproduce or distribute any part of it in any form, please obtain permission.

Requests for permission to reproduce material from this work should be sent to permissions@press.princeton.edu

Published by Princeton University Press

41 William Street, Princeton, New Jersey 08540

6 Oxford Street, Woodstock, Oxfordshire OX20 1TR

press.princeton.edu

All Rights Reserved

Library of Congress Cataloging-in-Publication Data

Names: Libbrecht, Kenneth, author.

Title: Snow crystals : a case study in spontaneous structure formation / Kenneth G. Libbrecht.

Description: Princeton, NJ : Princeton University Press, [2022] | Includes bibliographical references and index.

Identifiers: LCCN 2020057327 (print) | LCCN 2020057328 (ebook) | ISBN 9780691200378 (hardback) | ISBN 9780691223629 (ebook)

Subjects: LCSH: Snowflakes.

Classification: LCC QC926.32 .L5295 2022 (print) | LCC QC926.32 (ebook) | DDC 548/.5-dc23

LC record available at https://lccn.loc.gov/2020057327

LC ebook record available at https://lccn.loc.gov/2020057328

British Library Cataloging-in-Publication Data is available

Editorial: Jessica Yao, Ingrid Gnerlich, Maria Garcia

Jacket Design: Layla Mac Rory

Production: Jacqueline Poirier

Publicity: Matthew Taylor, Amy Stewart

Jacket image courtesy of author

This book has been composed in Garamond Premier Pro

Printed on acid-free paper. $\infty$

Printed in the United States of America

10987654321 